\title{
COMPARTIMENTUL
}

POLITOLOGIE

CZU 327

DOI https://doi.org/10.52388/1812-2566.2021.3(94).01

\section{GEOSTRATEGY: THEORETICAL CONCEPTUAL APPROACHES}

\section{Svetlana CEBOTARI}

Doctor habilitat, associate professor,

State University of Moldova, Chisinau, Republic of Moldova

e-mail: svetlana.cebotari@mail.ru

orcid: https://orcid.org/0000-0001-9073-104X

\section{Carolina BUDURINA-GOREACII}

$\mathrm{PhD}$, university lecturer,

State University of Moldova, Chisinau, Republic of Moldova

e-mail: carolina.budurina@gmail.com

https://orcid.org/0000-0003-2406-4212

The concept of strategy in the usual vocabulary has become present, crossing a multitude of spheres of social, political, economic and organizational life, far exceeding the boundaries of a reserved use, including the military field. In contemporary language, the term , strategy" is no longer a quality confined to interaction between states at global level and, even more, to military interaction, but it is used to express the idea of organization, plan or planning. It can be used in the field of business or politics, at local, national or international level. Based on these reasonings, we are currently present in the wider use of the concept of strategy. At present, the concept of "geostrategy" is a topic increasingly used in the discourse of politicians, but it also becomes a topic on the table of representatives of the academic community. Currently, the term "strategy" refers to the relationship between space and strategy, referring to the impact of these areas on international relations. "Geostrategy". It becomes an object of study of the combinations between the geographical and the strategic factor in determining the position of a state towards its neighbors, towards the region, or towards other international actors. Often, international actors, in order to achieve certain interests, resort to the use of certain strategies. This article aims to analyze the main conceptual-theoretical approaches of the geostrategy phenomenon.

Keywords: strategy, politics, international relations, security, state.

\section{GEOSTRATEGIA: IDENTIFICĂRI CONCEPTUAL-TEORETICE}

Conceptul de strategie din vocabularul obișnuit a devenit prezent, traversând o multitudine de sfere ale vieții sociale, politice, economice, depășind cu mult limitele unei utilizări rezervate, inclusiv domeniul militar. În limbajul contemporan, termenul ,, strategie” nu mai este o calitate care se limitează doar la interacțiunea dintre state la nivel global sau la interacțiunea militară, ci este folosit pentru a exprima ideea de organizare sau planificare. Acesta poate fi utilizat 
în domeniul afacerilor sau al politicii, la nivel local, național sau internațional. Pornind de la aceste raționamente, actualmente suntem prezenți la întrebuințarea mai extinsă a conceptului de strategie. In prezent, conceptul de ,geostrategie" este un subiect tot mai des folosit în discursul politicienilor, dar devine și un subiect prezent pe masa de lucru a reprezentanților comunității academice. Actualmente, termenul de ,geostrategie” desemnează relația dintre spațiu și strategie, fäcând referire la incidențele acestor domenii asupra relațiilor internaționale. , Geostrategia” devine un obiect de studiu al combinațiilor dintre factorul geografic și cel strategic în determinarea poziționării unui stat față de vecinii săi, față de regiune, sau față de alți actori internaționali. Deseori, actorii internaționali, în scopul realizării unor interese, apelează la utilizarea anumitor strategii. Prezentul articol ișsi propune să analizeze principalele abordări conceptual-teoretice ale fenomenului de geostrategie.

Cuvinte-cheie: strategie, politică, relații internaționale, securitate, stat.

\section{GÉOSTRATEGIE: IDENTIFICATIONS CONCEPTUELLE-THÉORIQUE}

La notion de stratégie dans le vocabulaire commun est devenue présente, traversant une multitude de sphères de la vie sociale, politique, économique et organisationnelle, dépassant de loin les limites d'un usage réservé, dont le domaine militaire. Dans le langage contemporain, le terme " stratégie » n'est plus une qualité qui se limite à l'interaction globale ou militaire entre États, mais sert à exprimer l'idée d'organisation ou de planification. Il peut être utilisé dans les affaires ou la politique, localement, nationalement ou internationalement. Sur la base de ces raisonnements, nous sommes actuellement présents dans l'utilisation plus large du concept de stratégie. A l'heure actuelle, le concept de " géostratégie " est un sujet de plus en plus utilisé dans le discours des politiques, mais il devient aussi un sujet présent sur la table des représentants de la communauté académique. Actuellement, le terme "stratégie » renvoie à la relation entre espace et stratégie, faisant référence à l'impact de ces domaines sur les relations internationales. "Géostratégie"devient un objet d'étude des combinaisons entre le facteur géographique et le facteur stratégique pour déterminer la position d'un État vis-à-vis de ses voisins, vis-à-vis de la région, ou vis-à-vis d'autres acteurs internationaux. Souvent, les acteurs internationaux, pour atteindre certains intérêts, recourent à l'utilisation de certaines stratégies. Cet article vise à analyser les principales approches conceptuelles-théoriques du phénomène de la géostratégie.

Mots-clés: stratégie, politique, relations internationales, sécurité, état.

\section{ГЕОСТРАТЕГИЯ: КОНЦЕПТУАЛЬНО-ТЕОРЕТИЧЕСКИЕ ИДЕНТИФИКАЦИИ}

Понятие стратегии в общепринятом лексиконе стало использоваться, пересекая множество сфер соииальной, политической, экономической и организационной жизни, намного превышая пределы ограниченного использования, включая военную область. На современном языке термин «стратегия» больше не является качеством, которое ограничивается глобальнымм или военным взаимодействием между государствами, а используется для выражения идеи организации или планирования. Его можно использовать в бизнесе или политике на местном, национальном или международном уровне. Основываясь на этих рассуждениях, в настоящее время мы наблюдаем более широкое использование кониепии стратегии. В настоящее время понятие «геостратегия» все чаще встречается в дискурсе политиков, но оно также становится темой, присутствующей на столе представителей академического сообщества. Термин «стратегия» используется к отношениям между пространством и стратегией, подразумевая влияние этих сфер на международные взаимосвязи. «Геостратегия» становится объектом изучения сочетаний географического и стратегического факторов при определении позииии государства по отношению к своим соседям, региону или другим международным игрокам. Часто международные субъекты для достижения определенных интересов прибегают к использованию определенных стратегий. Данная статья направлена на анализ основных концептуально-теоретических подходов к феномену геостратегии.

Ключевые слова: стратегия, политика, международные отночения, безопасность, государство. 


\section{Introduction}

The concept of strategy in the usual vocabulary has become present, crossing a multitude of spheres of social, political, economic and organizational life, far exceeding the boundaries of a reserved use, including the military field. In contemporary language, the term "strategy" is no longer a quality confined exclusively to interaction between states at global level, but is used to express the idea of organization, plan or planning. It can be used in the field of business or politics, at local, national or international level.

,Strategy" has its etymology in the Greek stratum, which implies the army and agein, a component that means to lead. Strategos was the name given to the army commander; andstrategike meant the army leadership [6, p. 7]. In Athens, in $500 \mathrm{BC}$, Clisthene introduced the institution of strategists, grouped into a college of 10 members, who were in charge of organizing the army and fleet, with the recruits and with the diplomatic affairs. The oldest known work, belongs to the Chinese thinker Sun Tzu and comes from the sixth century BC. In his work, ,, The Art of War", Sun Tzu studies war as a branch of government, detaches characteristic elements of the analysis of military situations.

Another Athenian thinker and philosopher from the 5th-4th century BC, Xenophon, in his work, „Cyropaedia”, already makes the distinction between tactics and strategy. By tactics, the thinker understands the art of arranging and maneuvering with troops, starting with the smallest units. By strategy, as a science of the supreme commander, there are directed all the necessary forces and means in order to obtain victory. During this period, the first military theorists, named today strategists, appearin Greece. Thus, Enee Tacticien (4th century BC); Demetros from Faleron (4th century BC); Poseidonios (2nd century BC) and others described for the first time the strategic phenomenon. Especially here the first strategy treaty appears which was written by Aineis, around $360 \mathrm{BC}$ [14]. Among the works written during the Roman Empire can be noted Stratagemata by Frontinus and Treaty of Strategy by Onesandros, both in the first century of our era.

The most important work that depicted Roman military art, influencing the military literature until late in the Byzantine era, referred to the treaty of military art of Flavius Vegetius Renatus, dating from the middle of the 5th century. Byzantine strategists gathered and synthesized in their works the experience of antiquity, as well as a series of observations on the procedures of fighting the migratory peoples from the end of antiquity. Another work of the Byzantine period is the military art of Mauricius, dating from the beginning of the 7th century. In his work, Mauricius defined that: „The strategy includes the means used to deceive the enemies, such as choosing the moment, the place, the unexpected confrontations and the stratagems of all kinds [7, p.74].

\section{The emergence and evolution of the strategy}

After several decades, under the disintegration of the states in the European space, the preoccupations for the military theory were considerably diminished, where the emergence and development of capitalist relations with its political, economic and military consequences have determined an increased interest in studying the strategy. However, military art writings that appeared until the end of the eighteenth century failed to achieve a systematic analysis of the strategy or to deepen its content. The wars of the French revolution and then the wars of Napoleon represented a turning point in the evolution of military strategy, which is explained both by the scale of these wars and by the general conditions of the development of society, science and culture of that period. At the end of the eighteenth century, Lloyd and the German Bulow tried to systematize the prin- 
ciples of strategy, as principles of warfare. They noticed the existence of relations between politics and strategy, trying to develop a method of analyzing the military phenomenon. According to Bulow, the strategy is the science of executing troops outside the enemy's field of vision. Tactics is the science of troop maneuvers in the enemy's field of vision and their leadership in battle.

Napoleon called strategy an art. He formulated the principles of willpower, security and the economy of forces, and through his battles he offered shining examples of this art. Jomini, a well-known military theorist, sees strategy as the art of developing war projects that are compatible with state means.

Over time, the term of strategy has become universal, taking over in the world military art. Thus, in the Middle Ages and in the modern period, strategy became an art of war, which would indicate the ways of solving some complicated strategic situations. The first papers begin to appear, which lay the theoretical basis of the strategy. Thus, the strategy begins to be regarded as a science, which had as its object of study the armed struggle. Carl von Clausewitz makes a much broader foundation of the strategy in his work "About war". The author emphasizes a clear structure of the military art, and the strategy has a determined role in the planning and conduct of the armed struggle.In the mentioned work Carl von Clausewitz formulates a rational system of military art, in which the strategy occupies the central place, ensuring the connection with the policy and with tactics. Clausewitz notes that the essential element in defining the strategy is the purpose of the war. Since war is the continuation of politics by other means, the goals of war are set by politics, and strategy is the art of achieving political goals by using military means. The role and functions of the strategy are deduced by the Clausewitz from the characteristics of the armed struggle, considered as a whole of battles. Also, Clausewitz, for the first time, determines the principles of formation and organization of the armed forces, giving a clear description of the determining factors in the organization of the armed force. Based on the analysis of the Napoleonic wars, Clausewitz generalizes the principles of applying the armed forces, establishing certain rules of strategic action, which are current even today. Referring to the strategic art he writes: „The offensive aims for positive purposes, because it envisages the expulsion of the enemy. The defense pursues negative goals, because it provides for the simple maintenance of the existing situation" [1, p. 78]. Also, some fundamental rules of strategic action are described, namely: ,we will decide for strategic defense, when the enemy is superior to us; In a defensive war a great aim is pursued (the use of the enemy, the general battle; the use of fortresses to immobilize a significant force of the adversary); For strategic defense on the large rivers it is not reasonable to divide the forces equally along the river, but it is more suitable to observe and attack the enemy during the passage; For strategic defense on mountain ranges it is recommended that $1 / 3$ of the army is in reserve destined for attacking the main forces of the adversary, who managed to pass; In offensive strategy it is important to focus on two issues: the permanent completion of troops and the provision of communication channels [1, p. 81.]An important place in the work of Clausewitz ,, About War”, is occupied by the description of rules of organization of the strategic leadership of army. Thus, it is mentioned that at the strategic level a command shouldn't have more than 10 subordinate structures, because otherwise it may become inefficient. Regarding the organization of the armies, he recommends to be few chains of command between the tactical and the strategic level, presenting as argument different examples from history of military art.

Later, at the end of the nineteenth century and the beginning of the twentieth century, new factors of social development emerge, which put the imprint 
on how to understand and deal with the strategy. The industrialization of the states that resulted in the massive endowment of the armed forces with fighting technique has determined to pay greater attention to the connection between the strategy and the evolution of the military technique. New types of technique - aviation, tanks, submarines, automatic weapons, etc. - generate new tactical and strategic possibilities, such as: firepower and hit, mobility, surprise, frontal strikes and great depths. These have led to widespread strategic battles.

In the interwar period, the influence of the new weapons on the strategy is analyzed by a number of military theorists, such as Liddell Hart, Giulio Douhet, John Fuller, Charles de Gaulle, Vladimir Trandafillov, Alexandru Svecin, etc. During this period, Soviet military theorists, who paid particular attention to the development of the strategy and the principles of employing different categories of armed forces in the future war, contribute much to the development of the strategy, starting from the fact that victory can only be achieved through joint efforts to all categories of armed forces.

Following the Second World War, a number of political and military considerations and, in particular, the consequences of the technical-scientific revolution have led governments and many military experts to pay more attention to the strategy than in the past. In some countries, even special institutes of strategic studies have been set up.

During this period, the strategy evolved progressively, covering a much wider spectrum of action. Thus, it appears the idea that the strategy is responsible not only for the planning and conduct of the armed struggle, but also for the conduct of the war.

As the world evolves, we are witnessing what Herve Coutau Begarie calls in his book, ,Treaty of strategy, volume I, the extension of strategy", invoking three major aspects. The first refers to the permanence of the strategy, in the sense that it is no lon- ger limited to the period of war and armed conflict. The second aspect, regarding the extension of the strategy, refers to the affirmation of its nonmilitary dimensions, in the sense that the state also uses the other available power tools, for the strategic purpose. Thus, there are used political, diplomatic, economic and informational means alongside military instruments. Finally, the third expansion of the strategy occurs after the Second World War and leads to ,removing the strategy from the sphere of state and conflict, in order to apply it in future to any social activity". Thus, the strategy exceeds its status as an art and science eminently in the service of the state's power tools and which defines ways to use them effectively in time of peace or war.

Therefore, we are in the situation where a predominantly military concept is borrowed in the language of the decision-makers, however, it retains the fundamental meaning of a set of actions in order to achieve a specific purpose. In other words, irrespective of the scope, the strategy must meet specific objectives, with the aim of describing the ways of achieving the proposed goals.

Thus, at the present stage in the doctrines and manuals of strategy we identify several expressions and syntagms, which refer to the strategy such as:

- Strategy is the way of using the forces, resources and available means to reach the set goals or the strategy remains a science and an art of power,

- strategy is the science and art of employing the political, economic, psychological and military forces of a nation or a group of nations to give maximum support to policies adopted during the time of peace or war [6]; ,Strategy is the art and science of developing and employing the tools of national power in a synchronized and integrated way, to ensure the achievement of national or international goals.

At present, we are witnesses when the strategy has become universal and can be found in all areas of a stateadministration. Thus, the expressions of 
education strategy, economic strategy, information strategy and others are used more and more. Among the strategists of this period are: Edward N. Luttwak, Gheorghe Văduvă, General Beaufre, V. Sokolovskii, Herve Coutau Begarie. Finally, strategy, as a component of the art of leadership, has evolved from the art of commanding the army on the battlefield, to the art of leading a state. Today, the basic mission of the strategy, being called by Gheorghe Văduvă - ,the integral strategy", is to ensure the security and development of a state. Of course, in this complex process the strategy has a subordinate role to the policy and it is intended to answer the question - how to achieve the objectives set by the political component of the state with the available resources.

\section{Conceptual-theoretical identifications of the phenomenon ,geostrategy"}

The concept of strategy in the usual vocabulary has become present, crossing a multitude of spheres of social, political, economic and organizational life, far exceeding the boundaries of a reserved use, including the military field. In contemporary language, the term "strategy" is no longer a quality confined exclusively to interaction between states at global level, but is used to express the idea of organization, plan or planning. It can be used in the field of business or politics, at local, national or international level.

Thus, according to Webster's New Encyclopedic Dictionary, the strategy designates science and art to use political, economic, psychological, military forces [12, p. 1021].

In the Political Dictionary, the institutions of democracy and civic culture, S. Tămas considers that the term derived from military practice, but also is used in other fields, such as the politics, economy management, to name the mode of action, so as to achieve success in a competition in which two or more wishes are faced, each pursuing the same goal in conditions where all the parties involved cannot win [10, p. 240].

In this regard, the strategy is the science and art of using the political, economic, psychological and military forces of a state or group of states to provide maximum support in the successful assurance of policies adopted during peacetime or war. The term „military strategy”, which involves the science and art of using the forces of a nation (economic, demographic), including the armed forces, is used in the specialized literature to achieve the goals set by the policy in order to effectively promote vital interests against to current or potential enemies. Any strategy involves a duel of wills between opponents who use force to resolve existing conflicts between them, each aiming to make the opponent accept the conditions he wants to impose.

Also, the strategy represents the means, whose purpose is defined by the policy field, an operation that highlights the forces that have the power. Thus, the political strategy represents the action plan elaborated to succeed in competition with the opposition forces on the way to obtaining the maximum possible support in the electoral campaigns or in another kind of political campaigns. At the strategic level, it refers to the following aspects: the mode of action, the goals and objectives to be achieved, the execution time, the means and resources that will use the main directions of action on the economic, technological, social, legislative level [10, p.240]. Thus, according to the New Universal Dictionary of Romanian, the „strategy" is: 1) the most important part of the military art that deals with the preparation, planning and conduct of the war; 2) the military discipline that studies the great war operations, the preparation of the plans of the great battles [8, p.1400].

At the general level, the strategy currently refers to the process of achieving the objectives by transforming military actions into political results. On the one hand, according to the supporters of K. Clausewitz, 
the strategy has been defined in numerous formulations as having the objective of concentrating the military power for a political purpose, being beyond these dimensions. By strategy, O. Gray understands the use of force to achieve the goals of government. Hence the second consequence in defining the strategy derives from its rational-linear nature. The strategy includes the process of setting objectives, developing concepts and calculating the risks and benefits of engaging available resources (existing or created) in actions aimed at establishing a more favorable environment.In the specialized literature it is given the tripartite definition of the strategy as a combination between final goals or objectives, as well as the ways to achieve these objectives, means or resource [3, p. 124-125]. Power strategies are plans that actors use to develop and gain power to reach their goals. Strategies also include the extent to which a state is willing to use its power capabilities.

The strategy, according to the opinion expressed by $\mathrm{Zb}$. Brzezinski, is the management of geostrategic interests. Also, for Brzezinski, geostrategy is not equivalent to geopolitics. The concepts of geostrategy and geopolitics can be considered as a whole and as a part. The author argues that geostrategy is part of geopolitics.

Secondly, it would be good if the geostrategy was not limited to analyzing only the positions of conditions and possibilities of using military force in a certain space. This is because in the post-war period a process of diversifying methods and forms of control over space is noticed. Thus, military force can be considered as an important factor, but not the only component of the geostrategy.

Third, the geostrategy assumes the long-term character of the planning and the action, conditioned by the quality of the space, which is the basis for the geostrategic concept elaboration. Also, the geostrategy assumes the activity of the state on the international arena in relation to certain units and spaces. De- pending on the quality and the particularities of the space, the geostrategy can be classified / divided into terrestrial, maritime, aerial and cosmic. The impact of geostrategy can be global, macro-regional and on states. At the base of the strategy are aspects such as: choosing the territory as a space for expansion or extension; imposing under a certain form of control over the space (building military bases, annexations, imposing the sphere of influence, economic or cultural domination); determining the threats from the part of real and potential opponents or allies by creating alliances, unions, coalitions.

In this context, geostrategy can be considered as an important part of geopolitics, which characterizes the activity of the state on the international arena, directed towards the creation, maintenance and extension of power through the possession of a wider space. It is a purpose that can be achieved by both military and nonmilitary means. Geostrategy is the basis of the state's foreign policy which determines its direction and priorities in a given space.

A. Marincenko states that military strategy means the way, the purpose of training and the use of military force in combat. Generals and the admirals bear responsibility for the modalities, the methods of combat and the result of the use of the armed and maritime forces in combat. They are also responsible for the war preparation of the nations, the industry (including the military), and infrastructure (communication and connection paths). Thus, the aim of the war is determined by the political leadership peak. Military strategy and geostrategy become parts of politics; the last one being an element of geopolitics. According to A. Marincenco the geostrategy of the developed contemporary states is structured in three levels. The highest level of geostrategy refers to the national strategy, which includes lower levels of strategies in spheres and directions of nation development. It determines the goals of the nation's development, ensures the efficient use of spiritual and material 
resources, and directs the nation towards achieving the proposed goals. The second level of geostrategy is the national security strategy, often defined by „big strategy”, „defense strategy” and ,strategic doctrine”. The national security strategy includes the strategies of those spheres and directions, which are necessary for national security for development purposes. Usually, the national security strategy is formulated in an official document - The concept of national security. The third level - the military strategy, coordinates the military problems of the national security - the development of the military industry, the provision of military forces with military technique, armament, means of communication, ammunitions. Usually, the military strategy is formulated in the military doctrine of the states. By involving both main objectives and secondary objectives, J. L. Thompson presents the strategy as a means of achieving a goal [3]. G. Steiner in his work ,, Strategic Planning” includes several points regarding the strategy:

- The strategy refers to basic, directional decisions, goals and missions;

- The strategy is made up of the actions necessary to form those directions;

- The strategy answers the question: what are the goals we seek and how do we achieve them?

The strategy is used in various ways, but some are highlighted by H. Mintzberg, who listed five main uses of the word „strategy":

1. A plan - in the sense of conscious, intended action, a mean of getting from here, that is, the distance between point $\mathrm{A}$ and point $\mathrm{B}$, where $\mathrm{A}$ represents the starting point, and $\mathrm{B}$ - the destination point;

2. A tactic - as a specific maneuver aiming to outclass opponents or competitors;

3. A pattern - represented by a sequence of actions;

4. A position - as a localization tool, in a certain environment;

5. A perspective - in the sense of an integrated way of perceiving the world, vision and directives [9].

These patterns of decisions and actions define the emerging strategy or, according to Mintzberg - an ,achieved strategy".

A key aspect of the strategy refers to the choice of the types of capabilities to be developed in order to maximize international influence. Strategies also include choices about how capabilities are used in various situations. These are sequences of actions built for maximum effect, alliance creation and the use of backup plans. Depending on the situation, most power strategies combine economic instruments (trade, aid, loans, investments, boycotts) with military ones (in the short term, these plans, within a situation are called tactics). Strategies also include the extent to which a state is willing to use its power capabilities.

Thus, in the specialized literature there are the following ways of realizing the strategies. According to C. Sorokin, in the literature there are three types of geostrategies:

1) Expansionists - which imply penetration in the near or far vicinity, often using force or threat with force;

2) Of surrender - which admit the physical restriction of the state territory;

3) Of positioning - oriented towards maintaining the status quo or the basic position [13, p.72].

In the opinion of realists, the strategy is often associated with the neoconservative, supportive of exclusive national sovereignty and focused on the development of military capacity as the main device for organizing the balance of power against opponents. On the other hand, according to the liberal current, the strategy represents the institutional development of international cooperation mechanisms [4, p. 117118]. Thus, the term ,strategy" is far from being a static concept, being in a constant transformation as a result not only of the evolution of the war techno- 
logies, but rather of the degree of complexity of the societies.

All these variables also have an international dimension, which is reflected in the way the geopolitical actors, especially the states as great powers, see their role in world politics. Starting with the size of the territory, the geographical location and its resources - all variables acquire value in forming and realizing interests. Each state has its economic, demographic, military, technical-scientific and cultural potential. The geopolitical location of the state during the historical evolution dominated in the choice of the partners and the development of relations with its opponents. The conditions of the geographical space are considered as basic causes; whose presence implies a certain political orientation of the state. The close geographic-political space correlation, under the imperative of the principle of causality, allows, in the researchers' conception, the possibility of generalizations, the formulation of laws and principles of universal validity, which will help to the theoretical foundation of geopolitics.

In the researches dedicated to the analysis of space, F. Ratzel considers that space is not equivalent to the territory of a state and it does not have a physical-geographical acceptance. The space designates the natural boundaries between which the expansion of peoples occurs, the area they tend to occupy, considering that it comes naturally to them, modeling the existence of the peoples that inhabit it $[5$, p.7475]. Also, in his research, F. Ratzel uses the term „geospace”, by which he understands the extension of the civilizing force of a civilization at the level of a continent (the American geospace) [5, p.76].

Another key notion used by F. Ratzel is that of position, a notion that is not strictly geographical, although it also has this dimension - strictly topographic, natural neighborhoods, having location in one or another hemisphere, relief shapes etc. The geographical location, according to Zb. Brzezinski, still remains the starting point in defining the external priorities of a state, and the size of the territory also remains one of the major criteria of stability of the state and power. But lately, for most states, the dominion of the territories loses importance. Leading elites have come to the conclusion that it is not the territory, but other factors that are most important in determining the international status of a country or its degree of influence on the international arena (economic development, technological innovations) can also be a key criterion of power. However, the geographical position tends to determine the immediate priorities of a state. The greater its political, economic and military power is, the more extended its immediate neighbors the sphere of vital geopolitical interests, influence and involvement of this state is [5].

Thus, space is a polysemantic and polyvalent notion. From a philosophical point of view, space can be interpreted as an objective and universal form of the existence of matter, having the appearance of a whole with three dimensions, expressing the order of the coexisting objects of the real world. In the current sense, the notion of space expresses the ordering of material bodies in their reciprocal relations, using real and concrete support to man and his activities. Geopolitics is a discipline that analyzes the complex, two-way relationships, between human political activity and space. As a scientific approach geopolitics aims at political organization of space. In this sense, we can talk about a geopolitical space, in which the subspaces represent systemically integrated units, between which there are multiple interaction relations. Geopolitical space represents the superior expression of systemic integration of geographical and social-economic space, in a politically ordered configuration. The introduction of this notion is required, on the one hand, from the need for a quantitative approach to the territorial realities with which geopolitics operates, and, on the other, from the inadequacy of some notions, such as region, zone or 
area, to respond to all practical requirements. Regarding the relationship between geopolitical space and the notions of region, zone and area, often used in geopolitical analysis, it must be very well defined, starting from the reasoning that any geopolitical region (zone or area) can be considered a geopolitical space, however, the inverse relationship is not valid. Both the region, zone or area are defined by certain principles, between which homogeneity occupies the central place. The notion of geopolitical space can be assigned to any territory, provided the complex and integral analysis of all the relations between the geographical, social-economic and political components [5].

The specific properties of the geopolitical space derive from the quantitative and qualitative variability of the local, regional or global relations between the components of the natural, social, economic and political activity. The results of the formal multidimensional research on geopolitical space must be constantly confronted with the objective reality, because, on the one hand, many variables are omitted in the theoretical calculations, and, on the other hand, a given geopolitical space is not identical with itself. There is the possibility, in certain circumstances, that a given geopolitical space may overlap with a geographical or social-economic space. But it must always be known that the geopolitical space implies a variable geometry, which knows continuous conjunctural changes. Any geopolitical space is characterized both by quantitative particularities and by qualitative aspects. These are the results of the differentiated interaction between the components of the geopolitical environment. Thus, quantitative and qualitative properties are distinguished [5].

Quantitative properties refer exclusively to the measurable characteristics of the space, which are expressed through surfaces, distances, volume, etc. Qualitative properties aim at multidimensionality, continuity, coherence, organization, all expressing topological and morphological aspects that ensure the functionality of the geopolitical space. Based on these general considerations it can be admitted that the notion of geopolitical space is attributed to territorial entities of variable size, from the smallest geopolitical units (substantial geopolitical spaces) to the planetary geopolitical space. The geopolitical space, as a systemically structured territorial-political reality, is characterized by a series of distinct features.

Complexity is the main feature of geopolitical space. The geopolitical space is a systemic reality in which numerous subsystems coexist and interact. These are composed, in turn, of elements with specific behavior. In this sense, we can identify at the macro level a global system that integrates the regional subsystems, which are composed, in their turn, of national systems. Its entire internal, structural and functional organization indicates a strong resemblance to an open thermodynamic and informational system, in which the variability of the input flows produces changes and requires system reconfigurations caused by the presence of the interests of the great powers in a certain space. The open character explains its internal possibilities of self-regulation. The disappearance of one of the bipolar organization blocks of the global system has demonstrated the possibility of self-regulation through a structural and functional reconfiguration. The systemic organization of the geopolitical space causes it to react to any change, based on chain diffusion processes (the domino principle). Thus, the initial impulse generated by the reformist Gorbachev in the Soviet Union involved, in the decommissioning process, the entire regional space system [2].

Polarity is another feature of geopolitical space. Functionally, the geopolitical space presents numerous centers of power, of different ranks, which energize the whole system. The development of these centers of power depends on the nature of the relationships between them and the properties of the adja- 
cent areas. The geopolitical space can be conceived as a unitary whole, the result of an incidence of natural, historical, economic, demographic, social and political factors. This characteristic applies mainly to power centers, which are individualized, through genesis and the nature of the generated relations in the space of influence and in the international environment.

The geopolitical space has a dynamic character generated both by internal changes, as well as by the intervention of external factors, such as the presence of political, economic, social, cultural interests. The external actions of the geopolitical actors (big powers) impose a permanent dynamic in vertical level of the geopolitical space, causing permanent changes of the hierarchy, reorientations of the flows of matter, energy and information, the outline of new space subsystems generated by the restructuring of the previous network. All these changes are also reflected horizontally, where geopolitical systems and subsystems can be restricted [2].

The processes of narrowing and extending the spatial systems represent elements of functional continuity and discontinuity, but which, by their compensatory character and by placing them at a level higher than the previous one, ensures the functional specificity of the respective system. An eloquent example of the manifestation of all these features is the analysis of the enlargement of NATO and the enlargement of the EU, which, through its interests, produces a new reconfiguration of the Balkan region, but also of the Eastern space.

Currently, geostrategy represents a current that aims to take into account the world as a whole, to create a global picture on world political issues. Geostrategy had more affinities with geopolitics than with political geography. Geostrategy has sought to be active, recommending policies and strategies that should be followed by the governments of states where there are geostrategic concerns.
American admiral Alfred Thayer Mahan (18401914) was the first representative of the geostrategy. $\mathrm{He}$ is the author of several works, of which the most known are ,"The influence of maritime power on history” (1890) and ,, The problem of Asia” (1900), in which he sought to argue the need for control over the main colors of maritime navigation, to protect trade relations and to ensure the economic wellbeing of a particular state (understandable, first of all from the US point of view). Mahan sought to prove the existence of six fundamental factors, on which the maritime power would depend:

a. The geographical position - existing, for different states, of an exit to the sea or the Ocean (possibly to several seas or oceans), the degree of interconnection of the different maritime basins, the development of the continental borders considered vulnerable, the possibility of organizing strategic maritime bases, away from the national territory and to control, with their help, the great international trade routes.

b. The physical configuration of the coast of states: the existence of bays sheltered, estuaries, straits or peninsulas that can stimulate the development of life maritime, while their absence creates difficulties in the relations between the state and the sea. Here, the degree of interconnection of the marine life with the internal economic life is also taken into account, through the navigable rivers (which, however, are regarded as possible ways of entering by some invaders).

c. The extension of the coast and the natural conditions, favorable or unfavorable, for organizing its defense.

d. The human dimension of the state, which influences its capacity to constitute a commercial fleet and a powerful military navy.

e. National character - the commercial aptitudes of the population and its inclination towards the marine life. 
f. The character of the government - the ability of the state governing bodies to highlight the conditions offered by nature and the skills of the population.

In the work The Problem of Asia, A. Thayer Mahan emphasizes the geostrategic role of domination over the core area of the Eurasian continent (giving priority importance to Russia) and that of domination over the seas surrounding the Eurasian continent (where he sees, first of all, the importance of the Sea British), highlighting Britain's efforts to dominate the southern and eastern margins of Eurasia (by establishing bases in Gibraltar, Malta, Cyprus, the Suez Canal, in Aden, Oman, India, Lanka, Burma, Singapore, northern Borneo, Hong Kong and the Shandong Peninsula) and to minimize Russia's efforts to exit the Indian Ocean (by controlling the Persian Gulf, Iran and the buffer state, Afghanistan). He predicted the stronger interference in this Asian policy of the United States and Japan, which actually occurred later (beginning with the period between the two world wars).

In the United Kingdom, the main representative of geostrategy was Halford J. Mackinder (1861-1947), of anthropogeographic formation. In the work The Geographic Pivot of History (1904), as Mahan, in the Problem of Asia, it was emphasized the continental geographical space, first of all - on the Eurasian core area (heartland), which would have the possibility to dominate the whole world, as from a continental fortress, surrounded by a buffer zone (rimland), in a permanent dispute, and then by the ,World Ocean".

In Mackinder's original conception, the key to world domination would lie in Eastern Europe, which can ensure the supremacy over the so-called „world islands" (Eurasia and Africa), while the ,peripheral islands" (the Americas and Oceania) would be of secondary importance. In his later works from the interwar period and the World War II, Mackinder changed his mind, considering that the Eurasian core area could be counterbalanced by Western Europe and North America, which tend to form a community that is not separated but united by the North Atlantic Ocean (referred to as the „Median Ocean”). It is an idea that underpinned NATO's constitution.

To a large extent, Mackinder's ideas were retold, with minor tweaks [2], by Nicholas J. Spykman (1893-1943), an American of Dutch origin. According to him, the rimland would be the one who plays the key role in world politics and would be able to oppose the heartland.

Some contemporary geostrategists, such as the French Georges Chaliand and J.-P. Rageau (1982), conceive the world as a concentric circular structure, with several rings, which remind H. Mackinder's ideas, even if their influence of analysis on world systems is also visible: - the core of the central powers (the former Soviet Union and its political satellites), the maritime ring (corresponding to the rimland and surrounding the nucleus, starting from North Africa to Southeast Asia), the ring of maritime powers (North America, Western Europe and Japan), the ring of underdevelopment and poverty (Sub-Saharan Africa and most of Latin America, less the ,South Cone") and the southern developed ring (Chile, Argentina, Uruguay, South Africa, Australia and New Zealand)

Both Mahan's and Mackinder's geostrategic ideas have attracted considerable criticism, as a result of over-simplification of history and excessive influence of determinism. This does not mean that they have not influenced the entire foreign policy and military strategy of Western countries and, first of all, the USA, from the period between the end of the eleventh century and the middle of the twentieth century. Thus, Mahan's ideas were largely followed by US foreign policy, especially during Theodor Roosevelt's presidency. It resulted in occupying the archipelago of Hawai in order to control the center of the Pacific Ocean; in assuring domination over a number of islands, former Spanish, from Antilles (Cuba, Puerto 
Rico); in supporting the separation of the Republic of Panama from Colombia in order to deal with the authorities of the new republic obtaining a strip between the Caribbean Sea and the Pacific Ocean, in which the Panama Canal was built, intended to control the connections between the Atlantic Ocean and the Pacific Ocean, as well as ensuring the possible joint action of the US fleets in the two oceans [15].

The most recent geostrategies include Alexandr Severskii (1894-1974), of Russian origin and refugee in the U.S. He emphasized the role of military aviation in a conflict and was the main advocate for US air supremacy, especially during World War II, and after the war. His concept the ,decision area” of the world strategies would be, in fact, the Arctic, due to the smaller distance, over the North Pole, than on the West - East direction, between the regions of great strategic importance of the USA and those of the former USSR. The ideas of Severskii were also taken as a strategy official in the US and Canada. It refers to states that have given special importance to the installation of a sophisticated, comprehensive defense system of the North, with numerous air bases, radar stations and so on.

Of contemporary geostrategies, we must mention firstly Saul B. Cohen (born 1928, in Massachussets), the author of a highly commented work - , Geography and Politicsin a Divided World" (1963). According to S. Cohen, the whole world would be divided into five geostrategic regions, which would be none other than the spheres of influence of the United States, Ocean Europe, the former Soviet Union, China and India. These would interfere with areas of dispute, characterized by chronic political instability, such as the Middle East, Southeast Asia and Central and Eastern Europe, with frequent changes of political regimes and borders.

Saul Cohen's recommendations in the field of political-strategic orientations go in the direction of developing cooperation, of realistic acceptance of a geostrategic division of the world and not in that of conflict and military rivalry. In general, it can be seen that Cohen's ideas represent coordinates that have been followed, to a large extent, by world politics, especially the great powers of the last years, after 1989. The destabilization and fragmentation of Central-Eastern Europe, the emergence of numerous outbreaks of conflict in this disputed area, in the Caucasus and the Near East (in Bosnia-Herzegovina, Croatia, Kosovo-Metohia, Transnistria, Chechnya, Abkhazia, Mount Karabakh, Iraq, etc.) are evidence of the special political-geographical labors of the in this area, within which Romania has the chance to present itself as an island of stability and balance, the chance that it deserves to be much better used [15].

\section{Conclusions}

Thus, today's world is going through a very complex evolutionary stage, with a dynamic dominant component, but also with an inherited background that is expressed through a strong inertia. On the one hand, contemporary geostrategies emphasize increasing the importance of global economic exchanges, and reducing the role of strategic armament, however sophisticated it may be. It also determines the increasing role of superstate organisms (European Union) and states with a more dynamic economy (People's Republic of China, Japan, Germany, India), while decreasing the importance on the world chessboard of the states with a less dynamic economy, regardless of their political regime (Russia, Great Britain, France, all in turn, second-level powers), as well as increasing the interventionism of the world's first politico-economic and military power, the United States, which sometimes ignores the position of the United Nations.

At the same time, historical inertia continues to play a role worthy of consideration in the contemporary world [15]: The US continues to exercise 
its authority in the Latin American political-geographical space, where it often intervenes, directly or indirectly, when it considers that its authority is endangered (for example, in Panama, Grenada, Chile, Haiti, etc.), by openly supporting pro-American regimes; Russia seeks to maintain its authority over the space of the former Soviet Union by maintaining its strategic enclave in Kaliningrad (north of former East Prussia), intervening more or less in Abkhazia, South Ossetia, Mountain Karabakh, Transnistria, Tajikistan and supporting pro-regime (from Belarus); France intervenes systematically in the various conflicts of the former French and Belgian colonies in Sub-Saharan Africa (Côte d'Ivoire, Chad, Central African Republic, Democratic Republic of the Congo) and supports the pro-Western factions of the Near East (especially in Lebanon); United Kingdom seeks to maintain its former positions in the South Atlantic (intervention in the Falkland Islands) and in the Persian Gulf area (co participation in US intervention in Iraq). All the above explains why today's last fragments of the former colonial empires are retained, 60 years after the end of World War II.

\section{References}

1. CLAUSEWITZ, C. Despre război. București: Antet, 2006. p. 408.

2. DOBRESCU, P. Geopolitica. Bucureşti: Comunicare.ro., 2008, $422 \mathrm{p}$.
3. GHICA, L., ZULEAN, M. Politica de securitate naţională. Concepte, instituții, procese. Iași: Polirom, 2007, p.117-118.

4. GRECU, M., ȚĂRANU, A. Trupele ruse în Republica Moldova. Chișinău: Litera Internațional, 2004, $872 \mathrm{p}$.

5. FRĂSINEANU, D. Geopolitica. Ediția a II-a, revăzută şi adăugită. Bucureşti: Fundaţia România de Mâine, 2007, $332 \mathrm{p}$.

6. LOGOFĂTU, Gh. Elemente de strategie militară. Bucureşti: Editura militară, 1975. 340 p. B 255.

7. MAURICIUS. Arta militară. București: Editura Academia R.S.R., 1970. 424 p.

8. Noul Dicționar universal al limbii române. București: Litera Internațional, 2006.

9. PÎNTEA, I. Identitatea pericolelor existente şi probabile pentru interesele naţionale de bază ale Moldovei. Chişinău: Institutul de Politici Publice, 2001, p.33.

10. TĂMAS, S. Geopolitica, o abordare prospectivă. Bucureşti: Noua Alternativă, 1995, p. 201.

11. Webster's Third New International Dictionary of the English Language Unabridged, vol. III. MerrianeWebster, $7448 \mathrm{p}$.

12. Webster's New Encyclopedic Dictionary. Germany: Koneman, 1994.

13. СОРОКИН, К.Э. Геополитика современности и геостратегия России. Москва:РОССПЭН, 2009. 170 с.

14. РАЗИН Е. История военного искусства (XXXI в. до н.э.-VI в.н.э.). Санкт Петербург: Издательство „Полигон, 1994. 560 с

15. http://www.scritub.com/geografie/Geostrategia71954.php (accesat 06.05.2021) 